\title{
Physicochemical and Microbiological Quality of Shallow Groundwater in Lomé, Togo
}

\author{
Kossitse Venyo Akpataku ${ }^{1,2 *}$, Masamaéya D. T. Gnazou1, Tse Yawo Agbefu Nomesi3, \\ Phintè Nambo1, Komi Doni' ${ }^{1}$, Limam Moctar Bawa1, Gbandi Djaneye-Boundjou1 \\ ${ }^{1}$ Laboratory of Applied Hydrology and Environment (Ex Laboratory of Water Chemistry), University of Lomé, Lomé, Togo \\ ${ }^{2}$ Department of Chemistry, Faculty of Sciences and Techniques, University of Kara, Kara, Togo \\ ${ }^{3}$ Agency of Water and Sanitation for Africa, Office of Togo, Lomé, Togo \\ Email: *avenyo@gmail.com
}

How to cite this paper: Akpataku, K. V., Gnazou, M. D. T., Nomesi, T. Y. A., Nambo, P., Doni, K., Bawa, L. M., \& DjaneyeBoundjou, G. (2020). Physicochemical and Microbiological Quality of Shallow Groundwater in Lomé, Togo. Journal of Geoscience and Environment Protection, 8, 162-179. https://doi.org/10.4236/gep.2020.812010

Received: November 22, 2020 Accepted: December 19, 2020 Published: December 22, 2020

Copyright $\odot 2020$ by author(s) and Scientific Research Publishing Inc. This work is licensed under the Creative Commons Attribution International License (CC BY 4.0).

http://creativecommons.org/licenses/by/4.0/

\begin{abstract}
The present study aimed to assess the physicochemical and microbiological quality of shallow groundwater tapped by private boreholes for water sale in Togo's most urbanized coastal areas. Ninety-six (96) groundwater samples were collected at the water sale points for chemical and microbiological analyses using standard methods. The results showed that groundwater is predominantly acidic with fresh and brackish water of $\mathrm{Na}-\mathrm{Cl}$ type. High concentrations of dissolved inorganic nitrogen $\left(\mathrm{NO}_{3}^{-}, \mathrm{NH}_{4}^{+}\right.$and $\left.\mathrm{NO}_{2}^{-}\right)$and permanganate indices indicating potential organic matter were found. Among the major ions, $\mathrm{Na}^{+}(46.9 \%), \mathrm{Cl}^{-}(51.0 \%)$ and $\mathrm{NO}_{3}^{-}$(50.0\%) present the highest percentages of unsuitable concentrations compared to $\mathrm{WHO}$ guidelines. These findings indicate the control of the natural impact of seawater and lagoon system and anthropogenic pollution from domestic and urban wastes on groundwater's physicochemical quality. About $65 \%$ of groundwater samples did not comply with the drinking water guidelines for microbial indicators, including total mesophilic flora, thermotolerant coliforms, and sulfite-reducing anaerobes. The results showed the failure of sanitation and hygiene conditions around sampling points and fecal contamination from sewage, pit latrines, septic tanks, and refuse and waste disposal. The degradation of physicochemical quality is higher in the old and high-density built-up areas. Simultaneously, microbial contamination represents a high risk of contracting waterborne or hygiene-sanitation-related diseases in the whole study area. This study provides a global view of shallow groundwater's physicochemical and microbiological quality in the study area. Limitations and suggestions for future research are discussed.
\end{abstract}




\section{Keywords}

Shallow Groundwater, Saltwater, Nitrate, Fecal Contamination, Lome-Togo

\section{Introduction}

Groundwater is the most precious water resource for human survival and socio-economic development all over the world. However, groundwater quality can be affected negatively due to natural geological-hydrogeological conditions and human-induced factors (Shirazi et al., 2015; Ontiveros-Terrazas et al., 2020). In the last decade, the development of human activities have increased the pressure on groundwater and the degradation of its quality in rural as well as urban areas (Cronin et al., 2007; Umezawa et al., 2008; Chidya et al., 2016; Lapworth et al., 2017; Anornu, Gibrilla, \& Adomako, 2017; Akpataku et al., 2019).

Although groundwater in urban areas is sometimes contaminated with multiple contaminants at higher concentrations than in rural areas, one of the most prevalent pollutants in both regions is nitrate (Kuroda \& Fukushi, 2008; Diaw et al., 2020). Based on a long-term dataset, Graniel, Morris, \& Carrillo-Rivera (1999) showed a substantial change in the hydrochemical characteristic and nitrate contamination of groundwater due to urbanization in the city of Merida, Yucatan, Mexico. In urban areas, leaky sewage, septic tanks, industrial spillages, landfill leachates, and fertilizers used in gardens are more common nitrate sources (Kuroda \& Fukushi, 2008; Diaw et al., 2020). Many studies have focused on nitrate and other pollutants such as fluoride, arsenic, uranium, heavy metals, and pesticides, which limit the use of groundwater resources regarding human health hazards (Tiktak et al., 2004; Wen et al., 2013; Jadhav et al., 2015; Coyte et al., 2019).

Beyond chemical contamination of groundwater, people's exposure to microbial pathogens through drinking water causing subsequent illness is a global problem that concerns developing and developed countries (Douterelo et al., 2014; George et al., 2015; Kapembo et al., 2016). For example, Pitkänen et al. (2011) assessed microbial contamination of twenty (20) small community groundwater supplies in central Finland. They evidenced fecal contaminations by the appearance of Escherichia coli or intestinal enterococci in five (5) groundwater supplies, all managed by local water cooperatives. Groundwater vulnerability was due to on-site technical hazards such as inadequate wells construction and maintenance, enabling surface water to enter into the well, and the insufficient depth of protective soil layers above the groundwater table. In the municipality of Bumbu (Kinshasa, the Democratic Republic of Congo), Kapembo et al. (2016) identified fecal contamination of groundwater from mainly human origin using PCR amplification human-Bacteroides. They have also highlighted the potential human risk associated with the exposure to contaminated groundwater from wells due to the high level of nitrate and fecal indicator bacteria, including Escherichia co- 
Ii, Enterococcus, and total coliforms. Mazari-Hiriart et al. (2000) used groundwater bacterial indicators and pathogens and the relationship between water quality and diarrheal disease rates in Mexico City (Mexico) to suggest ways to improve the potential of environmental health indicators (EHI) by framing epidemiological data and the use of GIS. Viable counts, fecal coliforms, Vibrio cholera, total streptococci, sulfate-reducing bacteria, and Escherichia coli allowed indicating vulnerable zones to water quality deterioration in Tamil Nadu and Pondicherry coastal aquifers, South India (Keesari et al., 2015; Vasudevan et al., 2020). In the deeper part of these aquifers, sulfate-reducing bacteria's predominance supported the hypothesis of reducing conditions that may lead to possible arsenic contamination in groundwater (Keesari et al., 2015).

The primary water security and public health concerns in urban sub-Saharan Africa, particularly in the coastal cities of the Gulf of Guinea, are the chemical and microbial contaminations of shallow groundwater evidenced by high contents of nitrate, heavy metals, fecal coliforms, and fecal Streptococci in boreholes and dug wells water samples (Erah, Akujieze, \& Oteze, 2002; Takem et al., 2010; Gibrilla et al., 2011; Mande et al., 2012; Totin et al., 2013; Affum et al., 2015; Soncy et al., 2015). In-situ sanitation facilities, mainly pit latrines and septic tanks, are considered the dominant cause of microbiological contamination and a significant cause of nutrient loading to water sources (Lapworth et al., 2017). Groundwater in coastal areas can also evidence an accentuated salinization due to seawater's influence (Akouvi et al., 2008; Olufemi, 2010; Mohamed et al., 2020).

Like other African cities, the coastal town of Lomé experienced a socio-economic development and a galloping growth of the population with a rate of $6.1 \%$ per year these last years (MPRPDAT/DGSCN, 2011; MPT-Togo, 2013). Unfortunately, infrastructures of vital needs such as sanitation and drinking water supply systems have not kept pace with the city's expansion. The collective municipal sanitation system is minimal. Most of the time, septic tanks' construction does not respect the rules, and uncollected wastes become uncontrolled rubbish dumps. Domestic and industrial wastewaters are untreated before released into the environment (MPT-Togo, 2013). These features constitute potential sources of high contamination, both chemical and microbial, of the shallow aquifer, the primary and overexploited resource for drinking water in Lomé (Mande et al., 2012; Soncy et al., 2015; Gnazou et al., 2017). In addition to formal groundwater exploitation by the Togolese Water Company (TdE), the past decades have witnessed a proliferation of informal private boreholes (MEAHV, 2010). Generally, owners do not determine the quality of water intended for human consumption despite the regulatory texts. A better understanding of boreholes water sale's impact on water resources sustainability and public health is then required for decision-making concerning these informal activities. In this context, the present study aimed to assess the physicochemical and microbial quality of shallow groundwater and its suitability for drinking and domestic purposes in Togo's most urbanized coastal areas. A high-resolution sampling for physicochem- 
ical and microbial analyses was designed to provide a global view of groundwater quality. An approach integrating classical hydrochemical methods, and GIS, was used to evaluate the results based on WHO guidelines and the EU Drinking Water Directives.

\section{Study Area}

The coastal city of Lomé is located on the sedimentary basin of the Gulf of Guinea, namely the Keta basin that extends from Ghana to Nigeria. The study area lies between the latitudes $6^{\circ} 08^{\prime} \mathrm{N}$ and $6^{\circ} 18^{\prime} \mathrm{N}$ and the longitudes $1^{\circ} 5^{\prime} \mathrm{E}$ and $1^{\circ} 23^{\prime} \mathrm{E}$ (Figure 1). It covers over an area of around $360 \mathrm{~km}^{2}$ with 1.6 million inhabitants in 2010 (MPRPDAT/DGSCN, 2011). The climate is of subequatorial Guinean type, characterized by two rainy seasons (April to July and September to October) and two dry seasons (July to August and November to March) with an average rainfall of $900 \mathrm{~mm} /$ year. The average monthly temperatures range from $25^{\circ} \mathrm{C}$ (August) to $29^{\circ} \mathrm{C}$ (March) (Gnazou, 2008).

The geological context of the study area integrates that of the post-Paleozoic sedimentary series of the Gulf of Guinea (Ghana-Togo-Benin-Nigeria) set up by the opening of the Atlantic Ocean and starting with the Maastrichtian to end with the Quaternary series (Sylvain et al., 1986; Helstrup, 2006; Da Costa et al., 2013; Gnazou et al., 2015b). The hydrostratigraphy of the sedimentary basin counts four aquifers (Figure 2). They are represented by Quaternary formations,

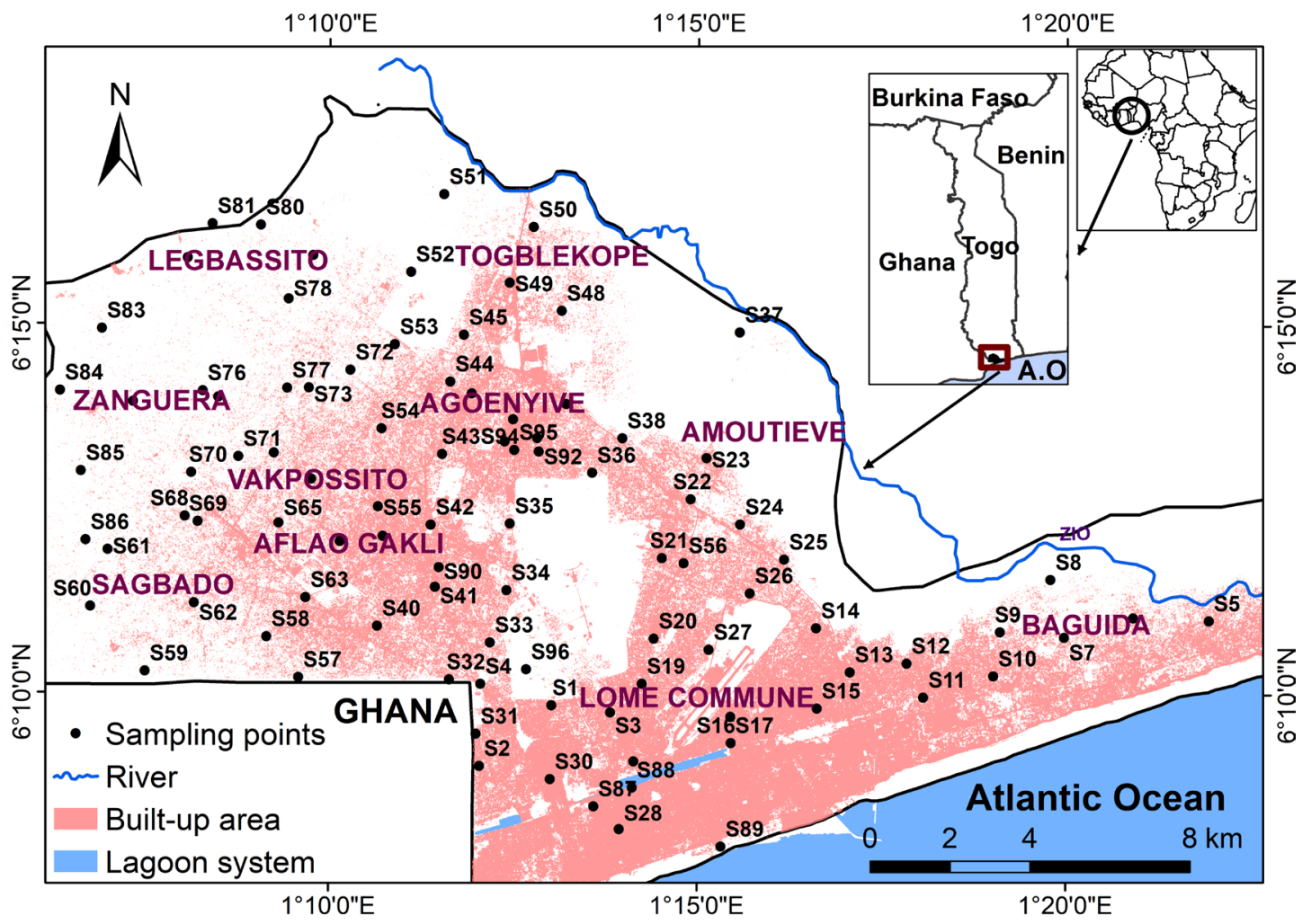

Figure 1. Location map and built up area estimated from SPOT 6 satellite image (acquired on December 8, 2015). 
Continental Terminal sands, Paleocene limestones and sands, and Upper Cretaceous (Maastrichtian) sands and sandstones (Gnazou et al., 2017). Private boreholes highly exploit the Continental Terminal aquifer for domestic purposes. Its average transmissivity is around $5 \times 10^{-3}$ to $8 \times 10^{-3} \mathrm{~m}^{2} / \mathrm{s}$, and the mean depth of boreholes is approximately $30 \mathrm{~m}$ below ground level ( $\mathrm{m} \mathrm{bgl}$ ). Figure 2 shows the geological North-South cross-section of Cretaceous-Quaternary sediments.

\section{Methodology}

\subsection{Groundwater Sampling and Analyses}

A total of 96 groundwater samples were collected from selected boreholes water sale points during December 2015 (Figure 1). The Global Positioning System (GPS: Garmin eTrex 20) was used to record sampling points' exact locations. Polyethylene bottles of $1.5 \mathrm{~L}$, washed and rinsed several times using water to be sampled, were used to collect samples for physicochemical analyses. For microbial assays, water samples were collected in sterile $\left(121^{\circ} \mathrm{C} / 25 \mathrm{mn}\right)$ glass bottles of $500 \mathrm{~mL}$. A burner was used to sterilize the taps before taking samples. The samples were labeled, stored at $4^{\circ} \mathrm{C}$, and transported to the laboratory for chemical and microbial analysis. $\mathrm{pH}$, dissolved oxygen, and electrical conductivity (EC) were measured in situ at each sampling point using HANNA portable equipment. Organoleptic parameters, total hardness, major and minor ions, and permanganate indices were determined. The microbiological analyses concerned the count of total mesophilic flora, thermotolerant coliforms, and sulfite-reducing anaerobes. Such indicator organisms can be used as surrogates due to the lack of specific pathogen data from water supplies (Llopis-González et al., 2014; George et al., 2015). Moreover, testing for all waterborne disease-causing organisms is not practicable due to the complexity, time-consuming, and expensive cost of the

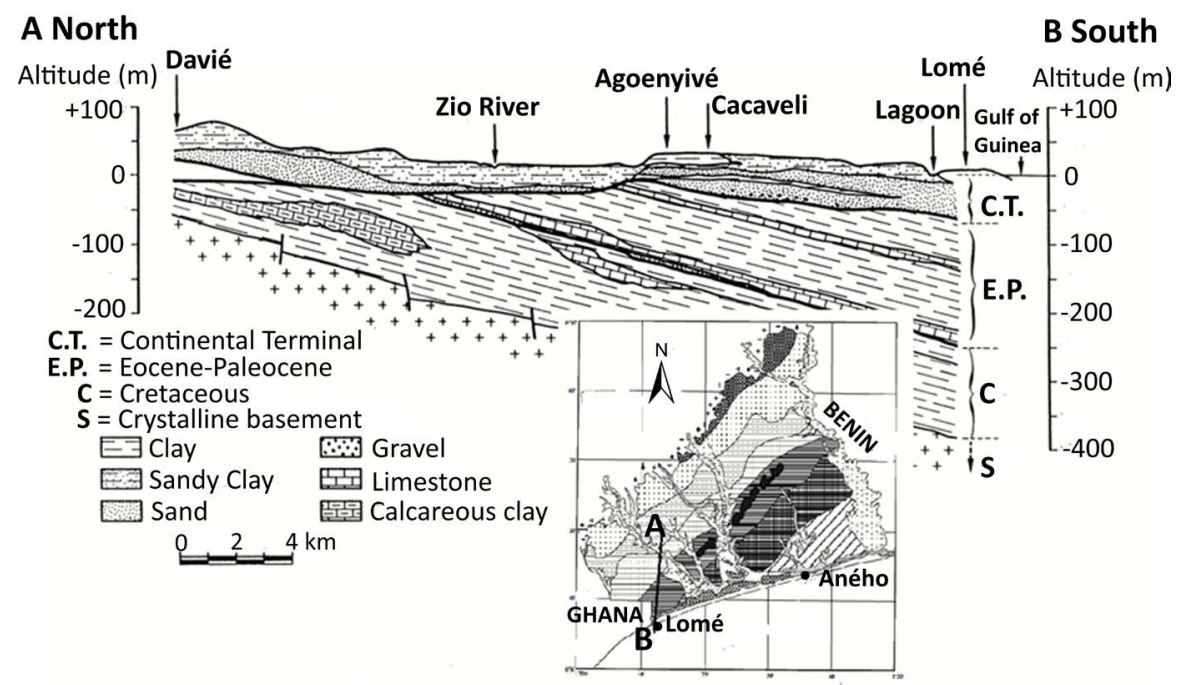

Figure 2. Geological North-South cross-section of Cretaceous-Quaternary sediments in the Coastal Sedimentary Basin of Togo. The location of the cross-section is shown on the inset (Helstrup, 2006; Gnazou et al., 2015b). 
tests (Gibrilla et al., 2011; Keesari et al., 2015). Therefore, testing was done for groups of thermotolerant coliforms and sulfite-reducing anaerobes that discriminate fecal contamination and total mesophilic flora to estimate sanitation and hygiene failure conditions around sampling points.

All analyses were carried out using the standardized methods of the French Association for Standardization (AFNOR) (Rodier et al., 2009) as described by Gnazou et al. (2015a) and Soncy et al. (2015).

\subsection{Data Treatment}

The hydrochemical and microbiological results were compared to WHO and EU water quality standards to assess the groundwater suitability for drinking and domestic purposes (European Union Council, 1998; WHO, 2011, 2018). Hydrochemical facies or water types indicating the dominants anion and cation in water samples were obtained using the Piper diagram (Piper, 1944). Sawyer \& McCarty (1967) classification was used to identify groundwater categories based on the total hardness content. ArcGIS software was used to produce the spatial distribution map of selected water quality parameters and assess groundwater quality's spatial variation and its relation with the built-up area density. The built-up areas map was estimated from the SPOT 6 satellite image acquired on December 8, 2015.

\section{Results and Discussions}

\subsection{Physicochemical Characteristics}

The statistical summary of the physicochemical results is presented in Table 1. All of the 96 water points sampled are odorless. 98\% of the samples are colorless ( $<5 \mathrm{mg} \mathrm{Pt} / \mathrm{L}$ ). The turbidity varied between 0.05 and 23.6 NTU. $94.8 \%$ of the water samples were clear water with values below the WHO guideline value of 5 NTU. 5.2\% were slightly turbid waters with values higher than 5 NTU. Higher turbidity results from suspended matter such as clay, silt, and organic matter. The temperature varied between $27.0^{\circ} \mathrm{C}$ and $34.3^{\circ} \mathrm{C}$ with a mean value of $30.3^{\circ} \mathrm{C}$ $\pm 1.0^{\circ} \mathrm{C}$. The $\mathrm{pH}$ values went from 4.19 to 7.56 , with an average of $5.73 \pm 0.72$, indicating predominantly acidic groundwater. About $81.3 \%$ of the samples have an unsuitable $\mathrm{pH}$ value than the WHO (2011) guideline range of 6.5 to 8.5. $\mathrm{pH}$ range is similar to that in groundwater from the portion CT aquifer in Benin (Alassane et al., 2015). Acidic groundwater was also indicated in the shallow coastal aquifer in Cote d'Ivoire (Yapo et al., 2010) and the unconfined sandy aquifer of Douala, Cameroon (Takem et al., 2015). These acidic water may result from co-factors' interplay, including atmospheric acid deposition from industries, municipal solid wastes incineration, urbanization-induced deforestation and acid-rain gas emissions, loads of organic matter and ammonium, and a low proportion of acid-consuming minerals such as carbonates in the aquifer matrix. Low $\mathrm{pH}$ is favorable to metal corrosion. Consequently, acidic groundwater may have an indirect effect on health since it may induce high mobility and high 
Table 1. Statistical summary of physicochemical results.

\begin{tabular}{|c|c|c|c|c|c|c|c|}
\hline Parameters & Min & $\operatorname{Max}$ & Mean & SD & $\begin{array}{c}\text { WHO } \\
\text { guideline }\end{array}$ & $\begin{array}{c}\text { Number of } \\
\text { unsuitable } \\
\text { samples }\end{array}$ & $\begin{array}{c}\% \text { of } \\
\text { unsuitable } \\
\text { samples }\end{array}$ \\
\hline Turbidity (NTU) & 0.05 & 23.6 & 1.35 & 3.39 & 5 & 6 & 6.3 \\
\hline $\mathrm{pH}(-)$ & 4.19 & 7.56 & 5.73 & 0.72 & $6.5-8.5$ & 78 & 81.3 \\
\hline Temperature $\left({ }^{\circ} \mathrm{C}\right)$ & 27.0 & 33.4 & 30.3 & 1.0 & & & \\
\hline $\mathrm{EC}(\mu \mathrm{S} / \mathrm{sm})$ & 253 & 6000 & 1477 & 1115 & & & \\
\hline TDS (mg/L) & 195 & 4548 & 1113 & 850 & 1000 & 42 & 43.8 \\
\hline $\mathrm{TH}\left(\mathrm{mg} \mathrm{CaCO}_{3} / \mathrm{L}\right)$ & 34 & 1301 & 283 & 240 & - & - & - \\
\hline $\mathrm{Na}^{+}(\mathrm{mg} / \mathrm{L})$ & 23.6 & 860.0 & 191.9 & 163.0 & 150 & 45 & 46.9 \\
\hline $\mathrm{K}^{+}(\mathrm{mg} / \mathrm{L})$ & $\mathrm{BDL}$ & 146.0 & 9.0 & 19.8 & $12^{\mathrm{a}}$ & 12 & 12.5 \\
\hline $\mathrm{Mg}^{2+}(\mathrm{mg} / \mathrm{L})$ & 3.8 & 156.0 & 30.7 & 26.6 & 50 & 9 & 9.4 \\
\hline $\mathrm{Ca}^{2+}(\mathrm{mg} / \mathrm{L})$ & 7.2 & 280.0 & 62.4 & 54.9 & 100 & 14 & 14.6 \\
\hline $\mathrm{Cl}^{-}(\mathrm{mg} / \mathrm{L})$ & 39.0 & 1950.0 & 360.3 & 354.0 & 250 & 49 & 51.0 \\
\hline $\mathrm{SO}_{4}^{2-} \quad(\mathrm{mg} / \mathrm{L})$ & 1.5 & 387.0 & 66.1 & 72.0 & 400 & 0 & 0.0 \\
\hline $\mathrm{HCO}_{3}^{-}(\mathrm{mg} / \mathrm{L})$ & 12.2 & 567.3 & 85.1 & 113.8 & $>30^{\mathrm{a}}$ & 30 & 31.3 \\
\hline $\mathrm{NO}_{3}^{-} \quad(\mathrm{mg} / \mathrm{L})$ & $\mathrm{BDL}$ & 445.0 & 77.0 & 81.1 & 50 & 48 & 50.0 \\
\hline $\mathrm{NO}_{2}^{-} \quad(\mathrm{mg} / \mathrm{L})$ & $\mathrm{BDL}$ & 5.5 & 0.2 & 0.7 & 3 & 2 & 2.1 \\
\hline $\mathrm{NH}_{4}^{+} \quad(\mathrm{mg} / \mathrm{L})$ & $\mathrm{BDL}$ & 13.0 & 0.6 & 1.9 & 1.5 & 8 & 8.3 \\
\hline $\mathrm{DO}\left(\mathrm{mgO}_{2} / \mathrm{L}\right)$ & 0.9 & 14.3 & 5.2 & 2.3 & 5 & 37 & 38.5 \\
\hline $\begin{array}{c}\text { Permanganate } \\
\text { indice }\left(\mathrm{mgO}_{2} / \mathrm{L}\right)\end{array}$ & $\mathrm{BDL}$ & 10.7 & 0.8 & 1.7 & - & & - \\
\hline
\end{tabular}

$\mathrm{BDL}=$ below detection limit; ${ }^{\mathrm{a} E U}$ drinking water directive.

concentrations of poisoning heavy metals (Appleyard et al., 2004; Takem et al., 2015).

The EC and TDS values varied vary between 253 and $6000 \mu \mathrm{S} / \mathrm{cm}$ and 195 to $4548 \mathrm{mg} / \mathrm{L}$ with mean values of $1477 \pm 1115 \mu \mathrm{S} / \mathrm{cm}$ and $1113 \pm 850 \mathrm{mg} / \mathrm{L}$ respectively, indicating a wide range of mineralization from fresh to brackish groundwater. Based on the WHO (2011) guideline, $43.8 \%$ of samples were not suitable for drinking purposes. In the Gulf of Guinea, the presence of fresh and brackish waters with TDS value up to $5336 \mathrm{mg} / \mathrm{L}$ were also identified in the shallow groundwater from the Lagos coastal basin, SouthWest Nigeria (Yusuf et al, 2018). These high mineralizations contrast with the dominance of fresh shallow groundwater from CT and Quaternary aquifers in other coastal cities in the Gulf of Guinea. For example, in Cotonou-Bénin, Douala-Cameroon, and Abidjan-Southern Ivory Coast, the TDS values rarely reached $1000 \mathrm{mg} / \mathrm{L}$ (Oga et al., 2008; Yapo et al., 2010; Takem et al., 2015; Alassane et al., 2015; Emvoutou et al., 2018). These results show a significant variation in groundwater mineralization, probably due to local processes. Very low to brackish TDS values were also 
found in groundwater from aquifers in large coastal cities worldwide (Keesari et al., 2015; Shi et al., 2018; Vasudevan et al., 2020).

The total hardness (TH) measuring calcium and magnesium contributions to water chemistry was determined and expressed in a quantity of $\mathrm{CaCO}_{3}$. In this study, values varied from 34 to $1301 \mathrm{mg} \mathrm{CaCO} / \mathrm{L}$ with a mean value of $283 \pm$ $240 \mathrm{mg} / \mathrm{L}$ (Table 1). Hard quality water type dominates in the study area (Table 2). Hard water type may induce excessive use of soap for cleaning. The increase of total hardness in water may also cause an unpleasant taste for consumers and scale formation (WHO, 2011). Few soft groundwater samples $(8.3 \%)$ showed low total hardness.

The main cations $\left(\mathrm{Ca}^{2+}, \mathrm{Mg}^{2+}, \mathrm{Na}^{+}\right.$, and $\left.\mathrm{K}^{+}\right)$were higher than the guideline values of $100,50,150$, and $12 \mathrm{mg} / \mathrm{L}$ in the order of $14.6,9.4,46.9$, and $12.5 \%$, respectively. The order of abundance of cations was $\mathrm{Na}^{+}>\mathrm{Ca}^{+}>\mathrm{Mg}^{2+}>\mathrm{K}^{+}$. The anions order of abundance was $\mathrm{Cl}^{-}>\mathrm{HCO}_{3}^{-}>\mathrm{NO}_{3}^{-}>\mathrm{SO}_{4}^{2-}$. Compared to the WHO guideline values, only the sulfate contents $\left(\mathrm{SO}_{4}^{2-}\right)$ are fully admissible. $\mathrm{HCO}_{3}^{-}$ranged from 12.2 to $567.3 \mathrm{mg} / \mathrm{L}$ with a mean value of $85.1 \pm 113.3 \mathrm{mg} / \mathrm{L}$. $31.3 \%$ of the collected samples presented low concentrations of $\mathrm{HCO}_{3}^{-}$compared to the WHO minimum limit of $30 \mathrm{mg} / \mathrm{L}$ for drinking water. For $\mathrm{Cl}^{-}$and $\mathrm{NO}_{3}^{-}, 51.0 \%$ and $50.0 \%$ of the collected samples were higher than the guideline values of 250 and $50 \mathrm{mg} / \mathrm{L}$, respectively. TDS, $\mathrm{Na}^{+}, \mathrm{Cl}^{-}$and $\mathrm{NO}_{3}^{-}$present the highest percentages of unsuitability. The spatial distribution of these hydrochemical parameters is presented in Figure 3. It shows that unsuitable samples are located mainly in the old and high-density built-up areas. In contrast, freshwater water samples with admissible nitrate concentrations are mostly distributed in the low built-up zones in the North to the West of the study area. This distribution supports the hypothesis of groundwater quality deterioration by urban wastewater, on-site sanitation facilities, and the intrusion of seawater and lagoon system water.

The trilinear Piper diagram was used to display the major ions composition of groundwater graphically (Figure 4). The majority of samples showed cationic and anionic compositions dominated by $\mathrm{Na}^{+}$and $\mathrm{Cl}^{-}$respectively, resulting in $\mathrm{Na}-\mathrm{Cl}$ water type in the study area. The predominance of $\mathrm{Na}-\mathrm{Cl}$ water type was also found in other studies of the coastal shallow aquifers along the Gulf of Guinea and explained by the strong influence of coastal sea aerosol spray, atmospheric deposition, and saline water intrusion from seawater and lagoon systems, on groundwater quality (Olufemi, 2010; Totin et al., 2013; Takem et al., 2015;

Table 2. Classification of groundwater based on the total hardness.

\begin{tabular}{cccc}
\hline Total hardness $\left(\mathrm{mg} \mathrm{CaCO}_{3} / \mathrm{L}\right)$ & Water type & Number of samples & Percentage (\%) of samples \\
\hline$<75$ & Soft & 8 & 8.3 \\
$75-150$ & Moderately hard & 20 & 20.8 \\
$150-300$ & Hard & 42 & 43.8 \\
$>300$ & Very hard & 26 & 27.1 \\
\hline
\end{tabular}




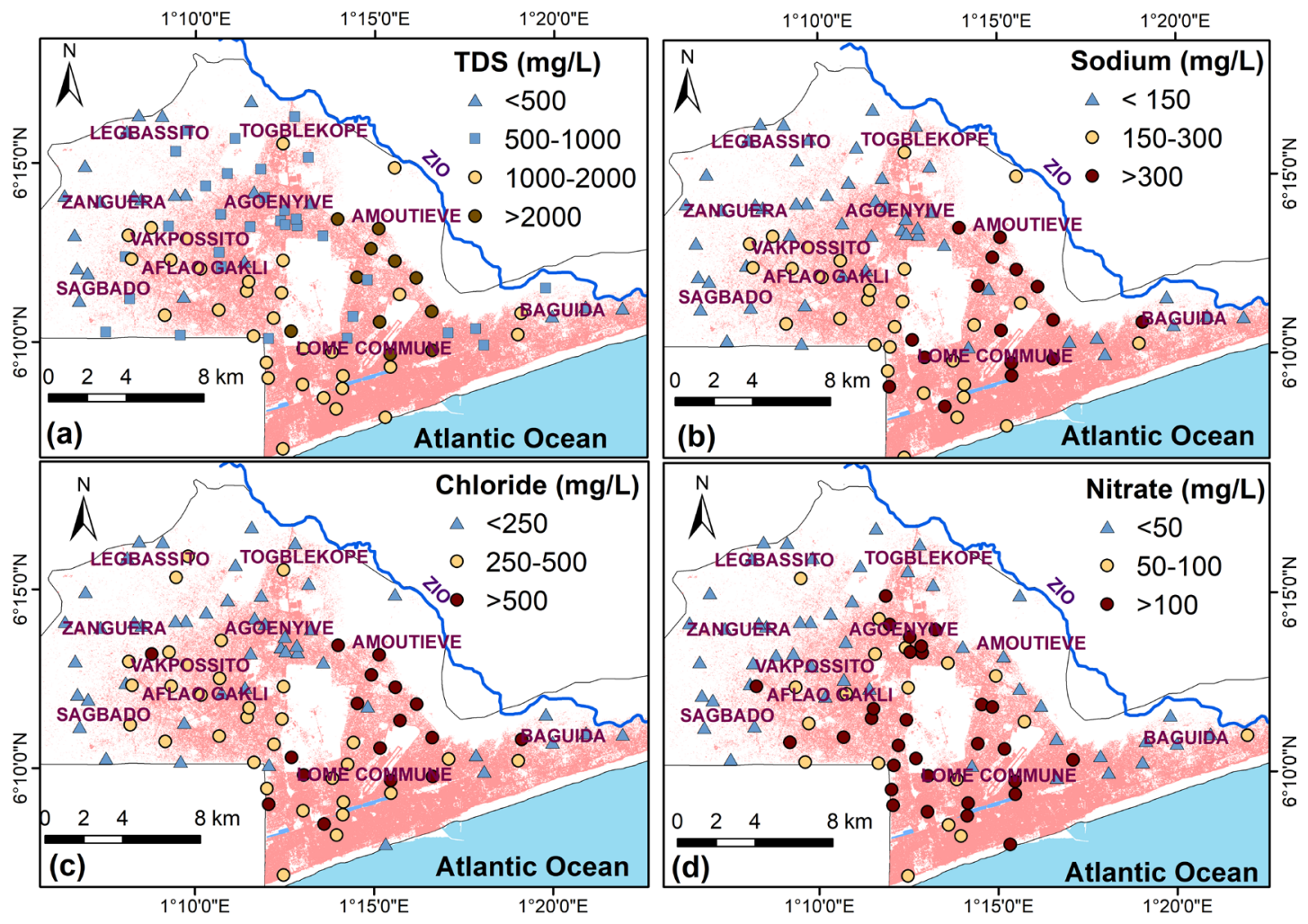

Figure 3. Spatial distribution of Selected parameters (a) TDS; (b) sodium, (c) chloride and (d) nitrate.

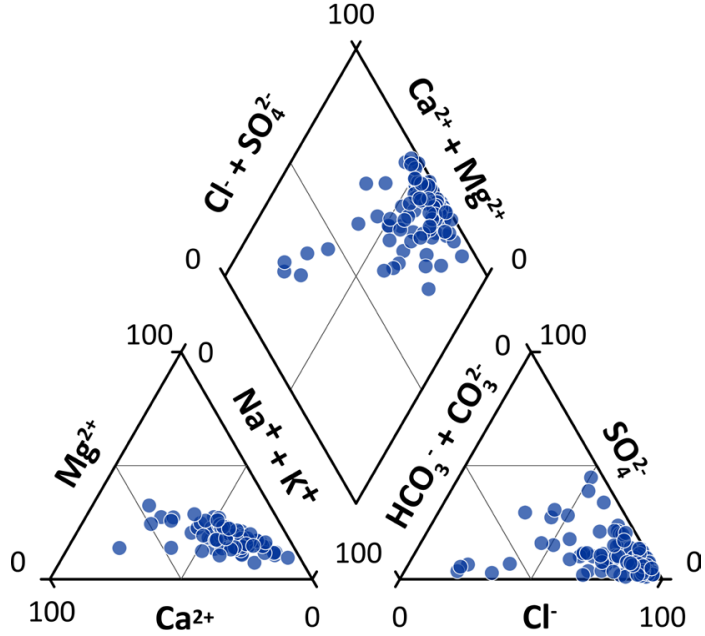

Figure 4. Piper diagram showing the predominance of $\mathrm{Na}-\mathrm{Cl}$ water type.

Alassane et al., 2015; Yusuf et al., 2018). The presence of accessories water types such as $\mathrm{Ca}-\mathrm{Mg}-\mathrm{HCO}_{3}, \mathrm{Ca}-\mathrm{Mg}-\mathrm{Cl} / \mathrm{SO}_{4}$, and $\mathrm{Na}-\mathrm{HCO}_{3}$ may indicate the influence of carbonaceous debris, gypsum, and concrete materials dissolution (Shi et al., 2018). The proportion of these calcic and bicarbonate water types may increase at a greater distance from the coastline due to less impact of saltwater (Akouvi et al., 2008; Alassane et al., 2015).

Dissolved inorganic nitrogen could be present in reduced nitrate forms such as nitrite $\mathrm{NO}_{2}^{-}$and ammonium $\mathrm{NH}_{4}^{+}$. Both components of dissolved inor- 
ganic nitrogen are minor in groundwater compared to nitrate. Their concentration varied from BDL to $5.5 \mathrm{mg} / \mathrm{L}$ and from $\mathrm{BDL}$ to $13.0 \mathrm{mg} / \mathrm{L}$ with mean values of respectively $0.2 \pm 0.7$ and $0.6 \pm 1.9 \mathrm{mg} / \mathrm{L}$ respectively. These results are consistent with the review of Lapworth et al. (2017), indicating ammonium concentrations ranging from $\mathrm{BDL}$ to $60 \mathrm{mg} / \mathrm{L}$ in urban groundwater from sub-Saharan Africa, while maximum concentrations were below $10.0 \mathrm{mg} / \mathrm{L}$ for most case studies. The acute toxicity of nitrate is attributed mainly to its conversion to nitrite resulting in risks of methemoglobinemia in infants and pregnant women and possibly cancer risks (Fan, 2011). High nitrate concentrations represent also inhibiting factors in human capacities (WHO, 2011; Adimalla, 2020). Ammonium does not pose an immediate risk to human health but suggests the presence of more serious residential contaminants (Umezawa et al., 2008). The cases of high concentrations of ammonium found in this study suggest groundwater contamination from sources such as pit latrines, dumpsites, septic tanks, sewer leakage, sewage effluent, and sewage sludge (Umezawa et al., 2008; Lapworth et al., 2017). High concentrations of $\mathrm{NO}_{2}^{-}$and $\mathrm{NH}_{4}^{+}$in some parts of the aquifer system reveals low dissolved oxygen, or prevailing anaerobic conditions limited or not to the sampling period (Böhlke, Smith, \& Miller, 2006; Umezawa et al., 2008). Besides, dissolved oxygen showed a wide range, consistent with the variability of the dissolved inorganic nitrogen components. Dissolved oxygen concentrations varied from 0.9 to $14.3 \mathrm{mg} / \mathrm{L}$ with a mean value of $5.2 \pm 2.3 \mathrm{mg} / \mathrm{L}$. About $38.5 \%$ of the values are below the minimum limit of $5 \mathrm{mg} / \mathrm{L}$ in drinking water (WHO, 2011).

Another common contaminant detected in urban groundwater is dissolved organic carbon (DOC), and further, it controls groundwater quality, microbial abundances, treatment coasts (McDonough et al., 2020). A significant association was depicted between DOC and fecal contamination parameters such as on-site sanitation and dissolved inorganic nitrogen in the city of Dakar, Senegal (Sorensen et al., 2020). The permanganate index was used to assess groundwater oxidability and speculate on the contamination by oxidizable organic matter. The permanganate index varied from $\mathrm{BDL}$ to $10.7 \mathrm{mgO}_{2} / \mathrm{L}$ with a mean value of $0.8 \pm 1.7 \mathrm{mgO}_{2} / \mathrm{L}$. The values higher than $0.5 \mathrm{mg} \mathrm{O}_{2} / \mathrm{L}$ were measured in $36.5 \%$ of the collected samples. These results contrast with the results obtained by Gnazou et al. (2015a) in the neighboring rural areas where values were BDL in boreholes. They measured high values in large diameter open wells and Zio River samples. The contrasting results from both studies may reveal the extent of organic matter and, consequently, organic carbon loading to groundwater system from municipal and domestic waste in Lome's city due to urbanization. However this interpretation is limited by the fact that in the permanganate test, volatile organic matter is not considered since the analysis is performed in a softly boiling solution, many organic compounds are only partially oxidized, and some oxidizable inorganic coumponds may contribute to the permanganate indice (Rodier et al., 2009). 


\subsection{Microbial Quality of Groundwater}

Microbial contamination indicators are important water-quality parameters since exposures to microbes from drinking water could imply severe public health problems through waterborne diseases (WHO, 2011; Gara et al., 2018). The statistical summary of the germs count is presented in Table 3 . The total mesophilic flora ranged from 0 to $2.1 \times 10^{4} \mathrm{CFU} / \mathrm{mL}$. About $60 \%$ of the collected samples exceeded the drinking water standard value of $100 \mathrm{CFU} / \mathrm{mL}$ (European Union Council, 1998). Results indicate aerobic bacteria's proliferation in the groundwater system in response to nutrients, dissolved oxygen, and organic carbon loads. Although total mesophilic flora is no longer used as a health-related indicator, it indicates significant deterioration of groundwater quality due to the failure of sanitation and hygiene conditions around sampling points (Bartram et al., 2003; WHO, 2018). The results indicate the poor cleanliness of water distribution systems and the absence of water disinfection at most boreholes' water supplies. Consequently, it appears a possible risk of pathogenic germs in groundwater used for drinking and domestic purposes in the study area.

The test of Escherichia coli in water provides evidence of recent fecal pollution originated from human and animal sources. Alternatively, testing the group of thermotolerant coliforms composed predominantly of $E$. Coli is regarded as an acceptable index of fecal pollution (WHO, 2011). The fecal coliforms or thermotolerant coliforms counts (FC) varied from 0 to $120 \mathrm{CFU} / \mathrm{mL}$ with $31.3 \%$ of samples above the guideline value of none detectable in any $100 \mathrm{~mL}$ of sample, indicating contamination from pit latrines, septic tanks, and sewage (European Union Council, 1998; WHO, 2018). Sulfite-reducing anaerobes (SRA) are also indicators of fecal contamination but represent germs that develop in the absence of oxygen and resist cooking. Their counts varied from nill to 130 $\mathrm{CFU} / \mathrm{mL}$, with almost $21 \%$ of collected samples above the guideline value, indicating riks to enteric viruses and protozoan (oo)cysts (WHO, 2018). These contaminated samples are also suggesting fecal pollution that took place previously or water points liable to intermittent contamination (WHO, 2011). However, results obtained in this study contrast with those of Gnazou et al. (2015a) and Soncy et al. (2015), who found fecal coliforms only in hand-dug wells but not in boreholes in and around Lome, Togo. Soncy et al. (2015) linked the difference in depth to the decrease of soil permeability due to clay content. The use of cased large diameter wells instead of boreholes at some water sale points can explain

Table 3. Microbiological germs loads in groundwater samples.

\begin{tabular}{cccccc}
\hline & $\begin{array}{c}\text { Minimum } \\
\text { CFU/mL }\end{array}$ & $\begin{array}{c}\text { Maximum } \\
\text { CFU/mL }\end{array}$ & $\begin{array}{c}\text { Parametric } \\
\text { values }\end{array}$ & $\begin{array}{c}\mathbf{N}^{\bullet} \text { of } \\
\text { unsuitable } \\
\text { samples }\end{array}$ & $\begin{array}{c}\text { Percentage (\%) } \\
\text { of unsuitable } \\
\text { sample }\end{array}$ \\
\hline $\begin{array}{c}\text { Total mesophilic flora } \\
\text { Thermotolerant or fecal } \\
\text { coliforms }\end{array}$ & 0 & $2.1 \times 10^{4}$ & 100 & 58 & 60.4 \\
Sulfite-reducing anaerobes & 0 & 120 & 0 & 30 & 31.3 \\
\hline
\end{tabular}


the result obtained. Fecal contamination can reach the deeper zone of the aquifer system due to hydrogeological conditions, inadequate borehole construction and maintenance, and the insufficient depth of protective soil layers above the groundwater table (Pitkänen et al., 2011; Llopis-González et al., 2014; Keesari et al., 2015).

Based on the three microbiological indicators used, about $65 \%$ of groundwater samples did not comply with the drinking water guidelines for human consumption. The spatial distribution of microbial quality of groundwater (not presented here) reveals no spatial coherence between the microbiological deterioration of groundwater quality and the built-up density as for the chemical aspect discussed above. Other studies also mentioned that the microbial contamination does not show a relationship with the density of on-site sanitation facilities and nitrate concentrations (Diaw et al., 2020), nor with the specific vulnerability classes established using COP and DRASTIC models (Llopis-González et al., 2014). These results evidence the necessity to consider both chemical and mirobiological aspects of groundwater quality to identify and rank vulnerable areas with a significant risk of groundwater quality deterioration.

It should be noted that this study focusing on the water quality at boreholes water sale points reveals the anthropogenic degradation of groundwater water quality in the study area. Groundwater mixing with the lagoon system is a potential source of groundwater contamination in addition to on-site sanitation facilities, leakage of municipal and industrial wastewater. Therefore, water resources interactions deserve considerations for future investigation with emphasis on additional contaminants such as pesticides, organic matter, polycyclic aromatic hydrocarbons, and trace elements including $\mathrm{As}, \mathrm{Cd}$, and $\mathrm{Pb}$, which were determined in coastal surface water and sediments (Gnandi et al., 2011; Ayah et al., 2015; Badassan et al., 2020). The consideration of the impact of the seasonal rainfall with hydrogeological conditions as well as the risk factors associated with each sampling point (the type of boreholes, boreholes drilling technic, borehole construction and maintenance, boreholes lining, proximity to and density of contamination sources, boreholes depth, static level, etc.) could provide evidence on the specific sources and mechanisms of groundwater contamination (Gibrilla et al., 2011; Llopis-González et al., 2014).

It is essential to educate water vendors and consumers about low-cost technology for drinking water treatment and hygiene and sanitation practices related to boreholes drilling and water sale activities in the current state. Implementation of a reliable municipal sewer system, frequent monitoring of a wide range of groundwater quality indicators, and in situ assessment of water supply infrastructures at the sale points are necessary to improve access to safe drinking and domestic water in the study area.

\section{Conclusion}

A high-resolution sampling was conducted to assess the physicochemical and 
microbial quality of shallow groundwater at water sale points in the coastal city of Lomé, Togo. The study showed the predominance of acidic and $\mathrm{Na}-\mathrm{Cl}$ water types with fresh or brackish character. TDS, $\mathrm{Na}^{+}, \mathrm{Cl}-, \mathrm{NO}_{3}^{-} \mathrm{NH}_{4}^{+}$, and dissolved oxygen present high percentages of unsuitable concentrations among physicochemical parameters compared to WHO guideline values. High permanganate indices representing potential organic matter were also observed. The degradation of groundwater's physicochemical quality is highly controlled by anthropogenic pollution from domestic and urban wastes, on-site sanitation facilities, and the natural impact of seawater and lagoon system. Abnormal levels of total mesophilic flora, thermotolerant coliforms, and sulfite-reducing anaerobes evidenced lack of water treatment before consumption, failure of sanitation and hygiene conditions around sampling points, and fecal contamination, indicating serious health hazards. The deterioration of groundwater's microbial quality also originates from sewage, pit latrines, septic tanks, refuse and waste disposal. The spatial analysis of physicochemical quality showed generally unsuitable boreholes water for drinking purposes in the old and high-density built-up areas. The distribution of the microbial quality of groundwater suggests that untreated boreholes water consumption represents a high risk of contracting waterborne or hygiene-sanitation-related diseases in the whole study area. The low correlation between the distribution patterns of chemical and microbial groundwater quality was not well understood. Moreover, this study does not provide evidence on the specific sources and mechanisms of groundwater contamination. The Consideration of the impact of the seasonal rainfall, hydrogeological conditions, and contamination risk factors associated with each sampling point could provide more insight into groundwater quality's temporal and spatial variation.

\section{Ethical Approval and Informed Consent}

Not applicable. The study does not involve human or animal subjects.

\section{Acknowledgments}

This work was supported financially by the Delegation of the European Union to Togo and the Agency of Water and Sanitation for Africa, Office of Togo.

\section{Conflicts of Interest}

The authors declare no conflicts of interest regarding the publication of this paper.

\section{References}

Adimalla, N. (2020). Spatial Distribution, Exposure, and Potential Health Risk Assessment from Nitrate in Drinking Water from Semi-Arid Region of South India. Human and Ecological Risk Assessment: An International Journal, 26, 310-334. https://doi.org/10.1080/10807039.2018.1508329

Affum, A. O., Osae, S. D., Nyarko, B. J. B., Afful, S., Fianko, J. R., Akiti, T. T. et al. (2015). Total Coliforms, Arsenic and Cadmium Exposure through Drinking Water in the West- 
ern Region of Ghana: Application of Multivariate Statistical Technique to Groundwater Quality. Environmental Monitoring and Assessment, 187, 1.

https://doi.org/10.1007/s10661-014-4167-x

Akouvi, A., Dray, M., Violette, S., de Marsily, G., \& Zuppi, G. M. (2008). The Sedimentary Coastal Basin of Togo: Example of a Multilayered Aquifer Still Influenced by a PalaeoSeawater Intrusion. Hydrogeology Journal, 16, 419-436.

https://doi.org/10.1007/s10040-007-0246-1

Akpataku, K. V., Rai, S. P., Gnazou, M. D.-T., Tampo, L., Bawa, L. M., Djaneye-Boundjou, G. et al. (2019). Hydrochemical and Isotopic Characterization of Groundwater in the Southeastern Part of the Plateaux Region, Togo. Hydrological Sciences Journal, 64, 983-1000. https://doi.org/10.1080/02626667.2019.1615067

Alassane, A., Trabelsi, R., Dovonon, L., Odeloui, D., Boukari, M., Zouari, K. et al. (2015). Chemical Evolution of the Continental Terminal Shallow Aquifer in the South of Coastal Sedimentary Basin of Benin (West-Africa) Using Multivariate Factor Analysis. Journal of Water Resource and Protection, 7, 496-515. https://doi.org/10.4236/jwarp.2015.76040

Anornu, G., Gibrilla, A., \& Adomako, D. (2017). Tracking Nitrate Sources in Groundwater and Associated Health Risk for Rural Communities in the White Volta River Basin of Ghana Using Isotopic Approach $\left(\delta^{15} \mathrm{~N}, \delta^{18} \mathrm{O}-\mathrm{NO}_{3}\right.$ and $\left.{ }^{3} \mathrm{H}\right)$. Science of the Total Environment, 603-604, 687-698. https://doi.org/10.1016/j.scitotenv.2017.01.219

Appleyard, S., Wong, S., Willis-Jones, B., Angeloni, J., \& Watkins, R. (2004). Groundwater Acidification Caused by Urban Development in Perth, Western Australia: Source, Distribution, and Implications for Management. Soil Research, 42, 579-585. https://doi.org/10.1071/SR03074

Ayah, M., Grybos, M., Tampo, L., Bawa, L. M., Bril, H., \& Djaneye-Boundjou, G. (2015). Qualité et pollution des eaux d'un hydrosystème littoral tropical: Cas du système lagunaire de Lomé, Togo. European Scientific Journal, 11, 95-119.

Badassan, T., Avumadi, A., Ouro-Sama, K., Gnandi, K., et al. (2020). Geochemical Composition of the Lomé Lagoon Sediments, Togo: Seasonal and Spatial Variations of Major, Trace and Rare Earth Element Concentrations. Water, 12, 3026.

https://doi.org/10.3390/w12113026

Bartram, J., Cotruvo, J. A., Exner, M., Fricker, C., \& Glasmacher, A. (2003). Heterotrophic Plate Counts and Drinking-Water Safety. London: IWA Publishing.

Böhlke, J. K., Smith, R. L., \& Miller, D. N. (2006). Ammonium Transport and Reaction in Contaminated Groundwater: Application of Isotope Tracers and Isotope Fractionation Studies. Water Resources Research, 42, W05411. https://doi.org/10.1029/2005WR004349

Chidya, R. C. G., Matamula, S., Nakoma, O., \& Chawinga, C. B. J. (2016). Evaluation of Groundwater Quality in Rural-Areas of Northern Malawi: Case of Zombwe Extension Planning Area in Mzimba. Physics and Chemistry of the Earth, Parts A/B/C, 93, 55-62. https://doi.org/10.1016/j.pce.2016.03.013

Coyte, R. M., Singh, A., Furst, K. E., Mitch, W. A., \& Vengosh, A. (2019). Co-Occurrence of Geogenic and Anthropogenic Contaminants in Groundwater from Rajasthan, India. Science of the Total Environment, 688, 1216-1227. https://doi.org/10.1016/j.scitotenv.2019.06.334

Cronin, A. A., Pedley, S., Hoadley, A. W., Kouonto Komou, F., Haldin, L., Gibson, J. et al. (2007). Urbanisation Effects on Groundwater Chemical Quality: Findings Focusing on the Nitrate Problem from 2 African Cities Reliant on On-Site Sanitation. Journal of Water and Health, 5, 441-454. https://doi.org/10.2166/wh.2007.040 
Da Costa, P. Y., Affaton, P., Salaj, J., Johnson, A. K. C., \& Seddoh, K. (2013). Biozonation des formations sédimentaires du bassin côtier du Togo (Afrique de l'Ouest). Revue Ivoirienne des Sciences et Technologie, 21-22, 45-73.

Diaw, M. T., Cissé-Faye, S., Gaye, C. B., Niang, S., Pouye, A., Campos, L. C. et al. (2020). On-Site Sanitation Density and Groundwater Quality: Evidence from Remote Sensing and in Situ Observations in the Thiaroye Aquifer, Senegal. Journal of Water, Sanitation and Hygiene for Development. https://doi.org/10.2166/washdev.2020.162

Douterelo, I., Boxall, J. B., Deines, P., Sekar, R., Fish, K. E., \& Biggs, C. A. (2014). Methodological Approaches for Studying the Microbial Ecology of Drinking Water Distribution Systems. Water Research, 65, 134-156. https://doi.org/10.1016/j.watres.2014.07.008

Emvoutou, H. C., Tandia, B. K., Nkot, S. N. B., Ebonji, R. C. S., Nlend, Y. B., Ekodeck, G. E. et al. (2018). Geologic Factors Controlling Groundwater Chemistry in the Coastal Aquifer System of Douala/Cameroon: Implication for Groundwater System Functioning. Environmental Earth Sciences, 77, Article No. 219.

https://doi.org/10.1007/s12665-018-7400-Z

Erah, P., Akujieze, C., \& Oteze, G. (2002). The Quality of Groundwater in Benin City: A Baseline Study on Inorganic Chemicals and Microbial Contaminants of Health Importance in Boreholes and Open Wells. Tropical Journal of Pharmaceutical Research, 1, 75. https://doi.org/10.4314/tjpr.v1i2.14587

European Union Council (1998). Council Directive 98/83/EC of 3 November 1998 on the Quality of Water Intended for Human Consumption. Official Journal of the European Communities, 330, 32-54.

Fan, A. M. (2011). Nitrate and Nitrite in Drinking Water: A Toxicological Review. In Encyclopedia of Environmental Health (pp. 137-145). Amsterdam: Elsevier. https://doi.org/10.1016/B978-0-444-52272-6.00563-8

Gara, T., Fengting, L., Nhapi, I., Makate, C., \& Gumindoga, W. (2018). Health Safety of Drinking Water Supplied in Africa: A Closer Look Using Applicable Water-Quality Standards as a Measure. Exposure and Health, 10, 117-128.

https://doi.org/10.1007/s12403-017-0249-7

George, J., An, W., Joshi, D., Zhang, D., Yang, M., \& Suriyanarayanan, S. (2015). Quantitative Microbial Risk Assessment to Estimate the Health Risk in Urban Drinking Water Systems of Mysore, Karnataka, India. Water Quality, Exposure and Health, 7, 331338. https://doi.org/10.1007/s12403-014-0152-4

Gibrilla, A., Bam, E. K. P., Adomako, D., Ganyaglo, S., Dampare, S. B., Ahialey, E. K. et al. (2011). Seasonal Evaluation of Raw, Treated and Distributed Water Quality from the Barekese Dam (River Offin) in the Ashanti Region of Ghana. Water Quality, Exposure and Health, 3, 157-174. https://doi.org/10.1007/s12403-011-0053-8

Gnandi, K., Bandowe, B., Deheyn, D., Porrachia, M., Kersten, M., \& Wilcke, W. (2011). Polycyclic Aromatic Hydrocarbons and Trace Metal Contamination of Coastal Sediment and Biota from Togo. Journal of Environmental Monitoring: JEM, 13, 2033-2041. https://doi.org/10.1039/c1em10063g

Gnazou, M. D. T. (2008). Etude hydrodynamique, hydrogéochimique, isotopique et modélisation de l'aquifère du Paléocène du bassin sédimentaire côtier du Togo. Thèse de Doctorat, Lomé: Université de Lomé.

Gnazou, M. D. T., Assogba, K., Sabi, B. E., \& Bawa, L. M. (2015a). Qualité physico-chimique et bactériologique des eaux utilisées dans les écoles de la préfecture de Zio (Togo). International Journal of Biological and Chemical Sciences, 9, 504-516. https://doi.org/10.4314/ijbcs.v9i1.43

Gnazou, M. D. T., Sabi, B. E., Lavalade, J. L., Schwartz, J., Akakpo, W., \& Tozo, A. (2017). 
Multilayered Aquifer Modeling in the Coastal Sedimentary Basin of Togo. Journal of African Earth Sciences, 125, 42-58. https://doi.org/10.1016/j.jafrearsci.2016.10.008

Gnazou, M. D. T., Sabi, B. E., Togbe, K. A., da Costa, Y. D., \& Agouda, K. (2015b). Actualisation structurale de l'aquifère du paléocène dans le bassin côtier du Togo. European Scientific Journal, ESJ, 11, 101-122.

Graniel, C. E., Morris, L. B., \& Carrillo-Rivera, J. J. (1999). Effects of Urbanization on Groundwater Resources of Merida, Yucatan, Mexico. Environmental Geology, 37, 303312https://doi.org/10.1007/s002540050388

Helstrup, T. (2006). Environmental Isotopic and Hydrochemical Characteristics of Groundwater from the Cretaceous-Eocene Limestone Aquifer in the Keta Basin, Ghana, and the Coastal Sedimentary Basin of Togo. PhD Thesis, Copenhagen: University of Copenhagen.

Jadhav, S. V., Bringas, E., Yadav, G. D., Rathod, V. K., Ortiz, I., \& Marathe, K. V. (2015). Arsenic and Fluoride Contaminated Groundwaters: A Review of Current Technologies for Contaminants Removal. Journal of Environmental Management, 162, 306-325. https://doi.org/10.1016/j.jenvman.2015.07.020

Kapembo, M. L., Laffite, A., Bokolo, M. K., Mbanga, A. L., Maya-Vangua, M. M., Otamonga, J.-P. et al. (2016). Evaluation of Water Quality from Suburban Shallow Wells under Tropical Conditions According to the Seasonal Variation, Bumbu, Kinshasa, Democratic Republic of the Congo. Exposure and Health, 8, 487-496.

https://doi.org/10.1007/s12403-016-0213-y

Keesari, T., Ramakumar, K. L., Prasad, M. B. K., Chidambaram, S., Perumal, P., Prakash, D. et al. (2015). Microbial Evaluation of Groundwater and Its Implications on Redox Condition of a Multi-Layer Sedimentary Aquifer System. Environmental Processes, 2, 331-346. https://doi.org/10.1007/s40710-015-0067-5

Kuroda, K., \& Fukushi, T. (2008). Groundwater Contamination in Urban Areas. In Ed. S. Takizawa (Ed.), Groundwater Management in Asian Cities: Technology and Policy for Sustainability (pp. 125-149). cSUR-UT Series: Library for Sustainable Urban Regeneration, Tokyo: Springer Japan. https://doi.org/10.1007/978-4-431-78399-2 7

Lapworth, D. J., Nkhuwa, D. C. W., Okotto-Okotto, J., Pedley, S., Stuart, M. E., Tijani, M. N. et al. (2017). Urban Groundwater Quality in Sub-Saharan Africa: Current Status and Implications for Water Security and Public Health. Hydrogeology Journal, 25, 1093 1116. https://doi.org/10.1007/s10040-016-1516-6

Llopis-González, A., Sánchez, A. L., Requena, P. M., \& Suárez-Varela, M. M. (2014). Assessment of the Microbiological Quality of Groundwater in Three Regions of the Valencian Community (Spain). International Journal of Environmental Research and Public Health, 11, 5527-5540. https://doi.org/10.3390/ijerph110505527

Mande, S. A.-S., Liu, M., Djaneye-Boundjou, G., Liu, F., Bawa, M. L., \& Chen, H. (2012). Nitrate in Drinking Water: A Major Polluting Component of Groundwater in Gulf Region Aquifers, South of Togo. International Journal of the Physical Sciences, 7, 144-152. https://doi.org/10.5897/IJPS11.874

Mazari-Hiriart, M., Cifuentes, E., Velázquez, E., \& Calva, J. J. (2000). Microbiological Groundwater Quality and Health Indicators in Mexico City. Urban Ecosystems, 4, 91-103. https://doi.org/10.1023/A:1011334326405

McDonough, L. K., Santos, I. R., Andersen, M. S., O’Carroll, D. M., Rutlidge, H., Meredith, K. et al. (2020). Changes in Global Groundwater Organic Carbon Driven by Climate Change and Urbanization. Nature Communications, 11, 1279.

https://doi.org/10.1038/s41467-020-14946-1

MEAHV (2010). Politique Nationale de l'Eau au Togo. 
Mohamed, M. L., Faye, S., Diongue, D. M. L., Emvoutou, H. C., Mohamed, A. S., \& Jiddou, M. (2020). Salinization Processes in the Benichab Coastal Aquifer-Mauritania. International Journal of Geosciences, 11, 720-726. https://doi.org/10.4236/ijg.2020.116020

MPRPDAT/DGSCN (2011). Quatrième Recensement Général de la Population et de l'Habitat (RGPH4): Résultats définitifs.

MPT-Togo (2013). Cadre de gestion environnemental et social du projet WARCIP-Togo.

Oga, M. S., Marlin, C., Dever, L., Filly, A., \& Njitchoua, R. (2008). Hydrochemical and Isotopic Characteristics of Coastal Groundwater near Abidjan (Southern Ivory Coast). In S. Adelana, \& A. MacDonald (Eds.), Applied Groundwater Studies in Africa (Vol. 13, pp. 371-389). IAH Selected Papers on Hydrogeology.

Olufemi, A. G. (2010). Assessment of Groundwater Quality and Saline Intrusions in Coastal Aquifers of Lagos Metropolis, Nigeria. Journal of Water Resource and Protection, 2, 849853. https://doi.org/10.4236/jwarp.2010.210100

Ontiveros-Terrazas, A. V., Villalobos-Aragón, A., Espejel-García, V. V., \& Espejel-García, D. (2020). Groundwater Quality and Its Impact on Health: A Preliminary Evaluation of Dental Fluorosis in Julimes, Chihuahua, Mexico. Journal of Water Resource and Protection, 12, 545-557. https://doi.org/10.4236/jwarp.2020.127033

Piper, A. M. (1944). A Graphic Procedure in the Geochemical Interpretation of Water-Analyses. Transactions, American Geophysical Union, 25, 914. https://doi.org/10.1029/TR025i006p00914

Pitkänen, T., Karinen, P., Miettinen, I. T., Lettojärvi, H., Heikkilä, A., Maunula, R. et al. (2011). Microbial Contamination of Groundwater at Small Community Water Supplies in Finland. Ambio, 40, 377-390. https://doi.org/10.1007/s13280-010-0102-8

Rodier, J., Legube, B., Merlet, N. et al. (2009). L'analyse de l'eau (9th ed.). Paris: Dunod.

Sawyer, C. N., \& McCarty, P. L. (1967). Chemistry for Sanitary Engineers (2nd ed.). New York: McGraw-Hill.

Shi, X., Wang, Y., Jiao, J., Zhong, J., Wen, H., \& Dong, R. (2018). Assessing Major Factors Affecting Shallow Groundwater Geochemical Evolution in a Highly Urbanized Coastal Area of Shenzhen City, China. Journal of Geochemical Exploration, 184, $17-27$. https://doi.org/10.1016/j.gexplo.2017.10.003

Shirazi, S. M., Adham, M. I., Zardari, N. H., Ismail, Z., Imran, H. M., \& Mangrio, M. A. (2015). Groundwater Quality and Hydrogeological Characteristics of Malacca State in Malaysia. Journal of Water and Land Development, 24, 11-19. https://doi.org/10.1515/jwld-2015-0002

Soncy, K., Djeri, B., Anani, K., Eklou-Lawson, M., Adjrah, Y., Karou, D. S. et al. (2015). Évaluation de la qualité bactériologique des eaux de puits et de forage à Lomé, Togo. Journal of Applied Biosciences, 91, 8464. https://doi.org/10.4314/jab.v91i1.6

Sorensen, J. P. R., Diaw, M. T., Pouye, A., Roffo, R., Diongue, D. M. L., Faye, S. C. et al. (2020). In-Situ Fluorescence Spectroscopy Indicates Total Bacterial Abundance and Dissolved Organic Carbon. Science of the Total Environment, 738, Article ID: 139419. https://doi.org/10.1016/j.scitotenv.2020.139419

Sylvain, J. P., Collart, J., Aregba, A., \& Godonou, S. (1986). Notice explicative de la carte géologique 1/500.0000 è du Togo. Direction Generale des Mines de la Géologie et du Bureau National de Recherches Minières Mémoire $\mathrm{N}^{\circ} 6$.

Takem, G. E., Chandrasekharam, D., Ayonghe, S. N., \& Thambidurai, P. (2010). Pollution Characteristics of Alluvial Groundwater from Springs and Bore Wells in Semi-Urban Informal Settlements of Douala, Cameroon, Western Africa. Environmental Earth Sciences, 61, 287-298. https://doi.org/10.1007/s12665-009-0342-8 
Takem, G. E., Kuitcha, D., Ako, A. A., Mafany, G. T., Takounjou-Fouepe, A., Ndjama, J. et al. (2015). Acidification of Shallow Groundwater in the Unconfined Sandy Aquifer of the City of Douala, Cameroon, Western Africa: Implications for Groundwater Quality and Use. Environmental Earth Sciences, 74, 6831-6846.

https://doi.org/10.1007/s12665-015-4681-3

Tiktak, A., de Nie, D. S., Piñeros Garcet, J. D., Jones, A., \& Vanclooster, M. (2004). Assessment of the Pesticide Leaching Risk at the Pan-European Level. The EuroPEARL Approach. Journal of Hydrology, 289, 222-238.

https://doi.org/10.1016/j.jhydrol.2003.11.030

Totin, H. S., Amoussou, E., Odoulami, L., Edorh, P. A., Boukari, M., \& Boko, M. (2013). Groundwater Pollution and the Safe Water Supply Challenge in Cotonou Town, Benin (West Africa). Proceedings of H04, IAHS-IAPSO-IASPEI Assembly, Gothenburg, July 2013, IAHS Publ. 361, 191-196.

Umezawa, Y., Hosono, T., Onodera, S., Siringan, F., Buapeng, S., Delinom, R. et al. (2008). Sources of Nitrate and Ammonium Contamination in Groundwater under Developing Asian Megacities. Science of the Total Environment, 404, 361-376.

https://doi.org/10.1016/j.scitotenv.2008.04.021

Vasudevan, U., Gantayat, R. R., Chidambaram, S., Prasanna, M. V., Venkatramanan, S., Devaraj, N. et al. (2020). Microbial Contamination and Its Associations with Major Ions in Shallow Groundwater along Coastal Tamil Nadu. Environmental Geochemistry and Health. https://doi.org/10.1007/s10653-020-00712-1

Wen, D., Zhang, F., Zhang, E., Wang, C., Han, S., \& Zheng, Y. (2013). Arsenic, Fluoride and Iodine in Groundwater of China. Journal of Geochemical Exploration, 135, 1-21. https://doi.org/10.1016/j.gexplo.2013.10.012

WHO (2011). Guidelines for Drinking-Water Quality (4th ed.).

WHO (2018). A Global Overview of National Regulations and Standards for DrinkingWater Quality. Geneva: World Health Organization.

Yapo, O., Mambo, V., Seka, A., Ohou, M., Konan, F., Gouzile, V. et al. (2010). Evaluation de la qualité des eaux de puits à usage domestique dans les quartiers défavorisés de quatre communes d'Abidjan (Côte d'Ivoire): Koumassi, Marcory, Port-Bouet et Treichville. International Journal of Biological and Chemical Sciences, 4, 289-307.

https://doi.org/10.4314/ijbcs.v4i2.58111

Yusuf, M. A., Abiye, T. A., Butler, M. J., \& Ibrahim, K. O. (2018). Origin and Residence Time of Shallow Groundwater Resources in Lagos Coastal Basin, South-West Nigeria: An isotopic Approach. Heliyon, 4, e00932.

https://doi.org/10.1016/j.heliyon.2018.e00932 